OPEN ACCESS

Edited by:

Nader Tanideh,

Shiraz University of Medical Sciences,

Iran

Reviewed by:

Farhad Rahmanifar,

Shiraz University, Iran

Emily Bryan,

Queensland University of Technology,

Australia

*Correspondence:

Behrouz Aflatoonian

b.aflatoonian@ssu.ac.ir

Specialty section:

This article was submitted to

Antimicrobials, Resistance

and Chemotherapy,

a section of the journal

Frontiers in Microbiology

Received: 29 September 2021

Accepted: 08 December 2021

Published: 13 January 2022

Citation:

Izadi M, Dehghan Marvast L, Rezvani ME, Zohrabi M, Aliabadi A, Mousavi SA and Aflatoonian B (2022) Mesenchymal Stem-Cell Derived Exosome Therapy as a Potential

Future Approach for Treatment of Male Infertility Caused by

Chlamydia Infection.

Front. Microbiol. 12:785622.

doi: 10.3389/fmicb.2021.785622

\section{Mesenchymal Stem-Cell Derived Exosome Therapy as a Potential Future Approach for Treatment of Male Infertility Caused by Chlamydia Infection}

\author{
Mahin Izadi',2, Laleh Dehghan Marvast ${ }^{3}$, Mohammad Ebrahim Rezvani4, \\ Marzieh Zohrabi ${ }^{1,2}$, Ali Aliabadi ${ }^{4}$, Seyed Alireza Mousavi ${ }^{5}$ and Behrouz Aflatoonian ${ }^{2,6,7 *}$
}

\footnotetext{
${ }^{1}$ Research and Clinical Center for Infertility, Yazd Reproductive Sciences Institute, Shahid Sadoughi University of Medical Sciences, Yazd, Iran, ${ }^{2}$ Department of Reproductive Biology, School of Medicine, Shahid Sadoughi University of Medical Sciences, Yazd, Iran, ${ }^{3}$ Andrology Research Center, Yazd Reproductive Sciences Institute, Shahid Sadoughi University of Medical Sciences, Yazd, Iran, ${ }^{4}$ Department of Physiology, School of Medicine, Shahid Sadoughi University of Medical Sciences, Yazd, Iran, ${ }^{5}$ Infectious Disease Research Center, Shahid Sadoughi University of Medical Sciences, Yazd, Iran, ${ }^{6}$ Stem Cell Biology Research Center, Yazd Reproductive Sciences Institute, Shahid Sadoughi University of Medical Sciences, Yazd, Iran, ' Department of Advanced Medical Sciences and Technologies, School of Paramedicine, Shahid Sadoughi University of Medical Sciences, Yazd, Iran
}

Some microbial sexually transmitted infections (STIs) have adverse effects on the reproductive tract, sperm function, and male fertility. Given that STIs are often asymptomatic and cause major complications such as urogenital inflammation, fibrosis, and scarring, optimal treatments should be performed to prevent the noxious effect of STIs on male fertility. Among STIs, Chlamydia trachomatis is the most common asymptomatic preventable bacterial STI. C. trachomatis can affect both sperm and the male reproductive tract. Recently, mesenchymal stem cells (MSCs) derived exosomes have been considered as a new therapeutic medicine due to their immunomodulatory, anti-inflammatory, anti-oxidant, and regenerative effects without consequences through the stem cell transplantation based therapies. Inflammation of the genital tract and sperm dysfunction are the consequences of the microbial infections, especially Chlamydia trachomatis. Exosome therapy as a noninvasive approach has shown promising results on the ability to regenerate the damaged sperm and treating asthenozoospermia. Recent experimental methods may be helpful in the novel treatments of male infertility. Thus, it is demonstrated that exosomes play an important role in preventing the consequences of infection, and thereby preventing inflammation, reducing cell damage, inhibiting fibrogenesis, and reducing scar formation. This review aimed to overview the studies about the potential therapeutic roles of MSCs-derived exosomes on sperm abnormalities and male infertility caused by STIs.

Keywords: exosomes, mesenchymal stem cells, Chlamydia trachomatis, infectious diseases, male infertility 


\section{INTRODUCTION}

A prominent etiological factor in male infertility is genital tract infection. The infertility may be induced by various mechanisms, such as damage to gametogenic cells, decrease in the quality of sperm, and obstruction of the male reproductive tract (Keck et al., 1998; Sanocka-Maciejewska et al., 2005). The most common sexually transmitted microorganisms are Chlamydia trachomatis (C. trachomatis) (Nieschlag et al., 1997; Keck et al., 1998; Ombelet et al., 2008). There are controversial opinions on the role of $C$. trachomatis in male infertility (Dehghan Marvast et al., 2017). Several studies have shown that male infertility induced by chlamydial infection occurs in different forms of sperm abnormalities such as loss of mitochondrial membrane potential, increase in apoptosis through the activation of caspase 3 (Sellami et al., 2014) and DNA damage (Dehghan Marvast et al., 2018), and changes in sperm quality (Bezold et al., 2007; Sellami et al., 2011, 2014). Also, other studies have claimed that this microorganism infection causes an inflammatory reaction which leads to seminal tubes occlusion (Dohle, 2003; Dehghan Marvast et al., 2016; Zhou et al., 2021). Many sexually transmitted infections (STIs) pathogens such as $C$. trachomatis are asymptomatic in subfertile men (Sharma and Agarwal, 1996; Bezold et al., 2007; Geisler, 2010; Hakimi et al., 2014; Bai et al., 2021). Screening and treatment should be performed to prevent the detrimental effect of C. trachomatis on male fertility (Geisler, 2010; Bryan et al., 2019). Widespread antibiotics are currently the most common treatment for chlamydial infection (Murray and McKay, 2021), and this treatment can effectively alleviate the infection and ameliorate sperm quality (Gallegos et al., 2008; Hamazah and AlDahmoshi, 2021). However, antibiotic resistance is one of the remaining challenges for this treatment, especially in patients with multidrug resistance (Hamazah and Al-Dahmoshi, 2021; Vanić et al., 2021).

The new experimental methods of the infertility treatment are stem cell and exosome applications. Because of the limitations using live cells injections and also the therapeutic effect of their paracrine substances (Janockova et al., 2021), MSC-derived exosomes containing bioactive molecules have been recently used in studies of infertility treatment. Exosome therapy as a noninvasive approach has shown promising results on the ability to regenerate damaged sperms and treating asthenozoospermia by their repairing molecules and counteracting with the reactive oxygen species (ROS) (Kharazi and Badalzadeh, 2020). These experimental methods may be helpful in the novel treatments of male infertility. This review aimed to overview the studies about the therapeutic potentials of the MSCsderived exosomes on sperm abnormalities and male infertility caused by STIs.

\section{TRACHOMATIS: CELL BIOLOGY}

Chlamydia is a gram negative bacterium, an obligate intracellular parasite, divided into 18 serovars (A-C, D-K, and L1-L3) distinguished by the antigen named the Major Outer Membrane
Protein. This antigen gives the pathologic properties to the serovars $\mathrm{D}-\mathrm{K}$ and may play an essential role in genital tract infection (Murray and McKay, 2021). Unlike other microorganisms, C. trachomatis has two distinct developmental cycles, the infectious type or elementary body (EB) and intracellular replicative type or reticulate body (RB). Both types of this bacterium are metabolically active, although their energy sources are different (Omsland et al., 2012). Expressions of different antigens during the cell cycle lead to difficulties in eradicating the bacterium (Paavonen and Eggert-Kruse, 1999; Murray and McKay, 2021). EB form attaches to the host cell and enters it and protects itself from host cellular defense by formation of vacuoles and inclusions (Hosseinzadeh et al., 2000).

\section{PATHOPHYSIOLOGICAL MECHANISMS}

Approximately $50 \%$ of C. trachomatis infections in men are asymptomatic, but it can cause epididymitis, epidiymo-orchitis, urethritis, and prostato-vesiculitis (Eley et al., 2005; Rana et al., 2016). Because of wide range of pathological changes and tissue injuries in the urogenital tract, it is necessary to briefly review the pathophysiology of $C$. trachomatis. This bacterium first attaches to the epithelial cells in the urogenital tract, and this is where immunological reactions are initiated. The infected non-immune cells recognize different invaded pathogens such as C. trachomatis by their PRRs (pathogen recognition receptors) (Mackern-Oberti et al., 2013). The interaction between non-immune host cell and bacterium leads to secretion of many cytokines (IL-1, IL-8, IL-6) (Al-mously and Eley, 2007; Redgrove and McLaughlin, 2014) and tumor necrosis factor alpha $(\mathrm{TNF} \alpha)$; these, in turn, recruit natural killer (NK) cells, DCs, neutrophils, macrophage, $\mathrm{T}$ cells, and B cells (Redgrove and McLaughlin, 2014). One of the most substantial cellular immune reactions against chlamydia infection is mediated by antigen-specific IFN- $\gamma$ secreting $\mathrm{CD} 4^{+}, \mathrm{CD} 8^{+} \mathrm{T}$ cells, and $\mathrm{NK}$ cells. Also, elimination of chlamydial infection depends on IFN$\gamma$ secreting CD4 ${ }^{+}$Th1 cells (Cain and Rank, 1995; Perry et al., 1997). Immune cells also generate chronic inflammation by increasing the production of ROS and releasing molecules with degradative properties including defensins, elastase, collagenase, cathespins, and lysozyme. Finally, the immune reactions lead to tissue remodeling and scarring in the reproductive system (Redgrove and McLaughlin, 2014).

\section{EFFECTS OF C. TRACHOMATIS ON SPERM AND MALE INFERTILITY}

Infertility in men is caused by various reasons such as genetic abnormalities, testicular damage, varicocele, immunological subjects, systemic diseases, environmental factors, endocrine disorders, and exposure to gonadotoxic agents (Dohle et al., 2004; Jungwirth et al., 2012). In addition to the above-mentioned factors, male genital tract infection and inflammation play a devastating role in $8-35 \%$ of male infertility. Infectious 
factors such as fungi, parasites, viruses, and several other microorganisms including C. trachomatis, Neisseria gonorrhoeae, Ureaplasma urealyticum, and Trichomonas vaginalis are involved in these disorders, which can affect the testis, epididymis, accessory sex glands, sperm cell function, and finally fertility (Isaiah et al., 2011). The most common cause is C. trachomatis, which leads to infertility by affecting both the sperm and the male reproductive tract (Nieschlag et al., 1997; Keck et al., 1998; Ombelet et al., 2008).

Some studies have regarded the relationship between C. trachomatis infection and semen quality. Semen of C. trachomatis infected patient indicates reduced volume, decrease in sperm motility, change in sperm concentration, and pH alteration (Veznik et al., 2004; Rana et al., 2016). It seems that aforementioned effects on the sperm can be due to Chlamydia lipopolysaccharide (LPS) which interacts with CD14 on the sperm membrane and leads to elevating production of ROS and eventually induced apoptosis (Harris et al., 2001). Another study demonstrated that $C$. trachomatis infection can cause rising in the mitochondria membrane potential, caspase 3 activation, and finally apoptosis induction in spermatozoa (Sellami et al., 2014). Moreover, externalization of phosphatidylserine (PS) in sperm membrane and DNA fragmentation has been reported as a negative impact of $C$. trachomatis on sperm function and fertility (Satta et al., 2006). In addition, several studies have reported infections of the reproductive system can cause leukocytospermia, and the leukocytes are able to produce oxidative damage of the sperm plasma membrane and DNA through the release of cytokines, free oxygen radicals, and reactive nitrogen (Anderson and Hill, 1988; Aitken and West, 1990; Hamada et al., 2011).

\section{CURRENT TREATMENT}

Current treatment includes azithromycin $1 \mathrm{~g}$ single dose or doxycycline $100 \mathrm{mg}$ orally twice daily for 7 days (Stamm et al., 1995; Dieterle, 2008; Mishori et al., 2012). Timely management of sexual intercourse and sex partner treatment are also necessary to reduce the re-infection risk (Centers for Disease Control and Prevention, 1998a,b; Workowski and Berman, 2011). Approximately 50\% of C. trachomatis infections in men are asymptomatic and can cause many complications (Pacey and Eley, 2004; Eley et al., 2005; Rana et al., 2016). Thus, screening programs are necessary to prevent long-term complications of $C$. trachomatis infection such as epididymitis, accessory sex glands inflammation, testicular atrophy, tubular tract occlusion, and male infertility (Paavonen and EggertKruse, 1999). While treatment with antibiotics significantly clears sexually transmitted patients, this treatment has its limitations (Kong et al., 2014). First, screening programs to identify chlamydia infected individuals are costly and impractical, so they are limited to symptomatic patients who are following their diseases (World Health Organization, 2016). Antibiotic therapy may also impair the production of a sustained protective immune response to chlamydia (Patton et al., 2014).
Vaccines have long been designed to treat chlamydia infection. Despite numerous successes in this field, there are still issues that have limited human access to deliver effective vaccines without complication. Biological characteristics, two-phase life cycle, and especially the ability of this bacterium to hide from the view of the immune system are the main reasons for this limitation in vaccine production. Providing a reliable and effective vaccine for Chlamydia prophylaxis is still awaiting further research and possibly shifting from whole-cell based vaccines to subunit-based vaccines, especially considering the role of MOMP (Murray and McKay, 2021).

Importantly, in some cases in which the complications still remained following antibiotic therapy, a new therapeutic approach is necessary for treatment. In this regard, MSCsderived exosomes have been shown to have critical roles such as anti-inflammatory, antioxidant, regenerative and fibrogenesis inhibiting, and wound and fracture healing (Janockova et al., 2021), which can be considered a novel approach in the male infertility complications of $C$. trachomatis infection.

\section{EXOSOME: GENERAL ASPECTS}

In different multicellular organisms, the intercellular communication occurs through cell-to-cell contact or through the secretion of molecules (Lai, 2004). Two decades ago, another mechanism was considered in the intercellular communication, which involves the transfer of extracellular vesicles that release from the plasma membrane into the intercellular space under physiological and pathological events and influence the other cells in paracrine and endocrine manners (György et al., 2011). Based on biosynthesis pathways and their size, the extracellular vesicles are divided into three categories: micro vesicles (503,000 nm), exosomes (40-100 nm), and apoptotic bodies (800-5,000 nm) (Yamamoto et al., 2016). Other studies have also mentioned other sizes for exosome: (30-100) (Wang et al., 2017), (50-150 nm) (Théry et al., 2018), (40-160 nm) (Kalluri, 2016), and (50-100 nm) (Gould and Raposo, 2013). Recently exosomes have attracted huge attention from researchers due to their genetic material and protein shuttling ability to other cells with various contents according to their origin (Han et al., 2016). Exosomes secrete from T cells (Nolte-'t Hoen et al., 2009), B cells (Clayton et al., 2005), macrophages (Bhatnagar et al., 2007), epithelial cells (Skogberg et al., 2015), endothelial cells (Song et al., 2014, 2015), as well as MSCs (Yeo et al., 2013). The vesicles with exosomal characteristics have been also founded in the various body fluids such as semen (Fabiani et al., 1994; Arienti et al., 1999; Park et al., 2011; Aalberts et al., 2012), blood (Blanc et al., 2005; Caby et al., 2005; Yunusova et al., 2016), breast milk (Admyre et al., 2007; Qin et al., 2016; Miyake et al., 2020), ascites fluid (Andre et al., 2002; Navabi et al., 2005; Runz et al., 2007), saliva (Ogawa et al., 2008; Michael et al., 2010), amniotic fluid (Asea et al., 2008; Zhang et al., 2021), urine (Gonzales et al., 2010; Street et al., 2017), and bile (Masyuk et al., 2010; Sagredo et al., 2017). Because exosomes are in nano sized range, they spread through body fluids and easily penetrate through tissues and affect targeted cells (Phinney and Pittenger, 2017), 
even if those cells are far away (François et al., 2006). The synthesis, secretion, and effects of the extracellular vesicles were intensively considered in the past few decades so that it led to the creation a scientific association named the International Society for Extracellular Vesicles (ISEV) (Kowal et al., 2014). Various techniques for isolation and detection of exosomes have been reported in recent studies. Isolation techniques include differential ultracentrifugation (Parolini et al., 2009), density gradient (Beyer and Pisetsky, 2010), size exclusion chromatography (Livshits et al., 2015), ultrafiltration (Greening et al., 2015), immunological separation (Beyer and Pisetsky, 2010), isolation by sieving (Taylor and Shah, 2015), cell sorting (Peterson et al., 2015), polymer-based precipitation (Grant et al., 2011), and microfluidic technologies (Oves et al., 2018). Exosome identification techniques include electron microscopy, western blot, flow cytometry, and nanosight tracking analysis (Crenshaw et al., 2018). The latest methods and techniques are RNA-seq techniques (Jeppesen et al., 2019).

\section{EXOSOME BIOGENESIS}

Exosome generation, which was conserved during evolution, is a continuation of the extracellular ligands internalization and endocytosis process, which is carried out by the curvature of the plasma membrane and budding inside the intracellular endosome that leads to the formation of multivesicular bodies (MVB). Later, the MVB, which contains intraluminal vesicles (ILVs) that can be the precursors of the exosome, either leads to fusion with lysosomes and degradation, or undergoes exocytic merging with plasma membranes and exosome secretion (Stoorvogel et al., 2002; Février and Raposo, 2004; Colombo et al., 2014; Kowal et al., 2014; Meldolesi, 2018; Xunian and Kalluri, 2020). Molecular mechanisms of ILV generation depend firstly on the endosomal sorting complex required for transport (ESCRT), a molecular apparatus comprised of four sets including ESCRT-0 which consists of two subunits HRS (hepatocyte growth factor-regulated tyrosine kinase substrate) and STAM1/2 (signal transducing adaptor molecule1/2) (for cargo clustering and sorting), ESCRT-I and ESCRT-II (induce membrane curvature and vesicle budding), and ESCRT-III (membrane deformation and vesicle detachment) (Henne et al., 2011; Meldolesi, 2018; Xunian and Kalluri, 2020). The subordinate proteins (Vps4-Vta1 complex, Tsg101, Vps24, Vps37, Vps2, and Alix) are also critical for exosome biogenesis pathway (Henne et al., 2011). ESRT apparatus is also involved in the deubiquitination of some proteins that are ubiquitinated in ILVs (Henne et al., 2011; Meldolesi, 2018). The deubiquitination is mediated by the protein tyrosine phosphatase HD-PTP, which is an essential process for exosome function (Meldolesi, 2018). The subordinate proteins (class I AAA ATPase Vps4) can cause the ESCRT apparatus recycling (Xunian and Kalluri, 2020). In addition to the ESRT pathway, there are other independent pathways, for example, ceramide derived from sphingomyelin can cause membrane deformation and vesicles budding within the MVB (Trajkovic et al., 2008; Henne et al., 2011).

\section{EXOSOME COMPOSITION}

Exosomes are extra cellular vesicles that are secreted from different cells under both normal and disease conditions and represent cells function or even as diagnostic markers of diseases. Existence of mRNA and miRNA within the exosomes has led to more studies in recent years, making this field more attractive (Valadi et al., 2007). The exosomes carry bimolecular content such as protein (membrane proteins, cytosolic and nuclear proteins, and extracellular matrix proteins), lipid, and nucleic acid which are different between cells (McAndrews and Kalluri, 2019). This content can be verified and accessed in the Exocarta, ${ }^{1}$ a manually curated web-based database. The current Exocarta is based on about 286 studies on exosomes and contains about 41,860 proteins, 1,116 lipid, and more than 7,540 RNAs from 10 various species (Keerthikumar et al., 2016). Several most common proteins on the exosomal surface such as tetraspanins (CD63, CD81, CD82, and CD9) are known as membrane scaffolds (Ma et al., 2020); in addition to the above-mentioned tetraspanins, in the MSCderived exosomes, there are expressions of CD73, CD44, and CD90 (Ramos et al., 2016). Exosomes present antigen proteins such as major histocompatibility complex (MHC) I and II, flotillin-1, and integrins. Other proteins include MVB biogenic proteins such as ESCRT complex 0,-1,-II,-III, Alix, syntenin, TSG101, membrane transporters, and fusion proteins such as RAB protein, RAP1B, RhoGDIs and annexins (Ma et al., 2020), several enzymes such as glyceraldehydes- 3phosphate dehydrogenase (GAPDH), phosphoglycerate kinase 1 (PGK1) (Van Niel et al., 2011; Charrin et al., 2014), and alanylaminopeptidase N (Ma et al., 2020), a number of chaperones such as heat shock protein 70 (HSP70), heat shock cognate 70 (HSC70) (Van Niel et al., 2011; Charrin et al., 2014), HSP90, HSP60, and HSP8 (Ma et al., 2020), adhesion proteins such as L1 cell adhesion molecule (L1CAM), and lysosomal associated membrane protein 2 (LAMP2) (Urbanelli et al., 2013).

Exosomes are also rich in genetic materials. Different types of RNAs including mRNAs and miRNAs, vault RNAs (vtRNAs), Y-RNAs, ribosomal RNAs (rRNAs), and transfer RNA (tRNAs) (Squadrito et al., 2014; Vojtech et al., 2014; Shurtleff et al., 2017). Also, various types of DNAs in exosomes are doublestranded DNAs (dsDNA) (Thakur et al., 2014), mitochondrial DNAs (mtDNAs) (Guescini et al., 2010), and single-stranded DNAs (ssDNAs) (Balaj et al., 2011).

Other exosome contents are lipid compositions including cholesterol, phosphatidylserine (PS), sphingomyelin, ceramide, lysobisphosphatidicacid, and phosphatidylethanolamine (PE), which play an important role in membrane structure and exosome formation and are secreted in the extracellular environment (Skotland et al., 2019).

Exosomes with lipid bilayer membrane can protect genetic material and other contents through transportation to the targeted cell (Fu et al., 2019). MSC-derived exosomes transmit their composition to the targeted cells either via plasma

\footnotetext{
${ }^{1}$ http://www.exocarta.org
} 
membrane fusion or membrane receptor function which lead to the exosome internalization (Harrell et al., 2019a).

\section{MESENCHYMAL STEM CELLS-DERIVED EXOSOMES}

MSCs which are mainly tissue specific stem cells can be isolated from adult (Akyash et al., 2020) and fetal (Hoseini et al., 2020) sources. MSCs can be also be produced from pluripotent human embryonic stem cells (hESCs) (Javidpou et al., 2021). Different cells secrete exosomes that have similar protein molecules and biological activities. Immune modulation, regeneration, tissue repair, and promotion of angiogenesis are the similar in vivo and in vitro therapeutic effects of MSC-derived exosomes. These similar activities may be related to the presence of common protein signature in all MSCs-derived exosomes (van Balkom et al., 2019). However, MSCs are a massive source for production of exosomes, more accessible, and highly proliferative (Cheng et al., 2017) and that makes them more suitable for different fields of research. Moreover, exosomes derived from specific types of MSCs have unique properties (Tang et al., 2021). Additionally, different specific cells secrete exosome containing unique protein molecules and exert biological activity (Simpson et al., 2008). For example, in a recent study, amelioration of the spermatogonia injuries by Sertoli cell-derive exosome was revealed (Salek et al., 2021).

\section{ROLE OF MESENCHYMAL STEM CELLS-DERIVED EXOSOMES IN INFLAMMATION AND CELLULAR DAMAGE}

Numerous studies have shown the potential of MSC-derived exosomes for treatment of diseases, which can be used as vaccines (prophylaxis), treatment, disease biomarkers, and drug delivery (Wang et al., 2017; Janockova et al., 2021).

It has been demonstrated that MSC-derived exosomes exhibit a crucial role in repair of the epithelium damage and reepithelialization (Zhang et al., 2015a), angiogenesis (Shabbir et al., 2015; Zhang et al., 2015b), and prevention of the scar formation by suppressed myofibroblast differentiation (Fang et al., 2016). Studies have also reported that MSC-derived exosomes containing miRNAs can reduce inflammation by transforming the pro-inflammatory macrophage M1 to antiinflammatory phenotype M2. The phenotype M2 reduces local interleukin-1 $\beta$, interleukin-6, and tumor necrosis factor alpha $(\mathrm{TNF}-\alpha)$ and increases the secretion of anti-inflammatory factors such as IL-10 as well as immune regulation (Wei et al., 2019; Zhao et al., 2019). Recent study demonstrated that MSC-derived exosomes can cause suppression of CD4 ${ }^{+}$Th1 and Th17 and induction of $\mathrm{T}$ regulatory cells (Treg) expansion which it in turn regulates and suppresses the immune system (Harrell et al., 2019b). Also, the protective effects of MSC-derived exosomes have been mediated via oxidative stress suppression and maintain balance of cellular redox state (Yang et al., 2015).

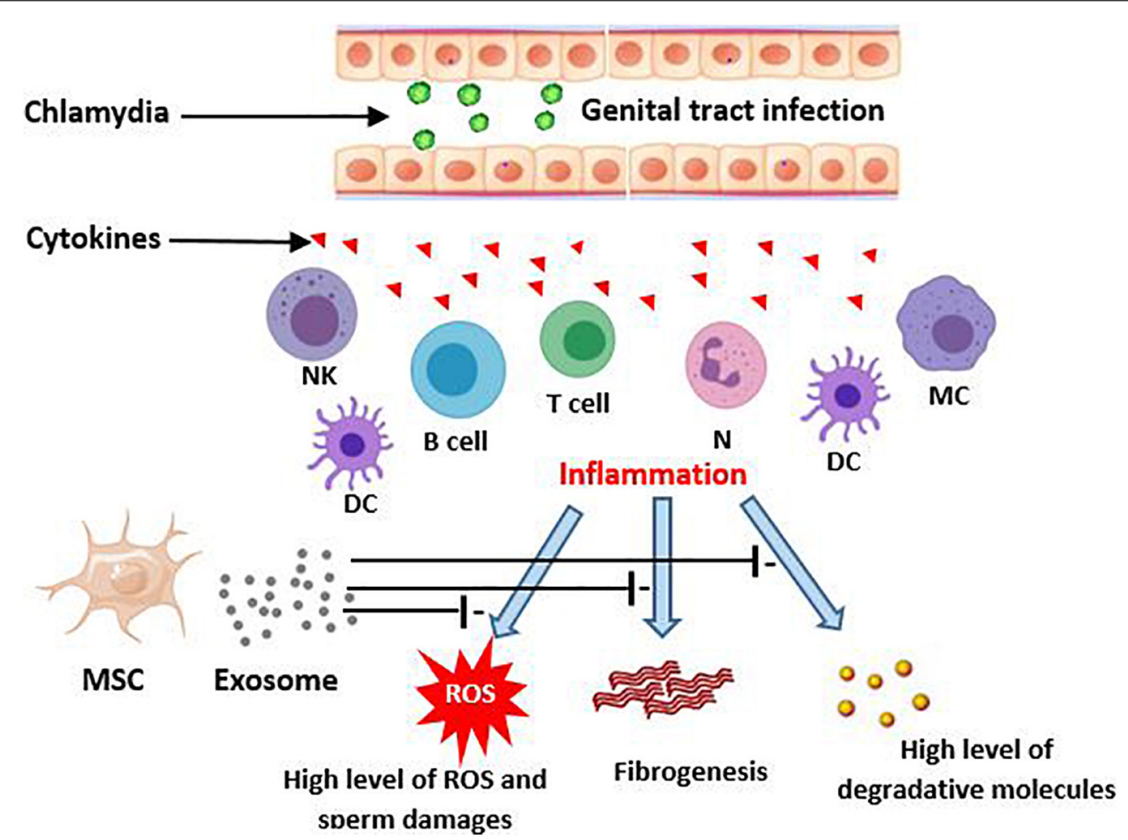

FIGURE 1 | Potential effects of MSCs-derived exosomes on consequences of chlamydia infection in the genital tract. Genitalia tract infection with chlamydia evokes an inflammatory immune response by epithelial and local immune cells. This, in turn, produces the high level cytokins that initiate a more severe immune reaction. The responses may result in male genital inflammation and fibrosis. On the other hand, the inflamed tissue can lead to creation of ROS production and then sperm damages. MSC derived exosomes potentially improve these consequences of chlamydia induced inflammation. DC, Dendritic cells; MC, Macrophage; NK, Natural killer; MSC, Mesenchymal stem cell; ROS, Reactive oxygen species. 
Studies have also shown the important role of MSC-derived exosomes in tissue repair after injury, the effect that is mediated by inducing cell differentiation, proliferation, and prevention of apoptosis. The miRNAs such as miR-21-5p, miR-144, and miR$19 \mathrm{a}$ are the factors that inhibit apoptosis in the MSC-derived exosomes and reduce apoptotic proteins such as caspase 3, caspase 8, and caspase 9 after tissue injury (Yu et al., 2015; Li et al., 2019; Wen et al., 2020).

In the inflammatory response of colitis it has been reported that MSC-derived exosomes attenuate inflammation through decrease in TNF- $\alpha$, nuclear factor kappaBp65 (NF-кBp65), cyclooxygenase-2 (COX-2), inducible nitric oxide synthase (iNOS), interleukin-1 $\beta$ (IL-1 $\beta$ ), and increase in expression of IL-10. Alleviation of LPS-induced inflammation and acute respiratory distress syndrome (ARDS) by MSC-derived exosomes has been demonstrated (Deng et al., 2020). Another study on premature ovarian failure reported that MSC-derived exosomes with miR-644-5p can cause apoptosis inhibition via impressing p53 and recover normal function in ovarian granulosa cell (Sun et al., 2019). Considering the male infertility caused by C. trachomatis has inflammation-based pathology (Lotti and Maggi, 2013; Redgrove and McLaughlin, 2014), exosome therapy may be a beneficial technique to attenuate the cell injuries and the tissue remodeling such as occurrence of fibrosis and scar formation (Figure 1).

\section{ROLE OF MESENCHYMAL STEM CELLS-DERIVED EXOSOMES IN INFECTION}

The antimicrobial properties of MSC-derived exosomes have been reported by several clinical trials (Krasnodembskaya et al., 2010; Harman et al., 2017; Cortés-Araya et al., 2018). Studies also showed that exosomes contain antimicrobial peptides (AMPs) and the proteins that have bactericidal effect (Gläser et al., 2005; Krasnodembskaya et al., 2010; Allen and Stephens, 2011; Alcayaga-Miranda et al., 2017). MSC-derived exosomes indicated the therapeutic effect on lung injury that induced by E. coli (Zhu et al., 2014). Also, enhancing anti-microbial function of immune cells infiltration in lung by MSC-derived exosome has been reported in an animal study (Hao et al., 2019). A previous study revealed that exosomes can protect the brain against sepsis induced in an experimental model (Chang et al., 2018). MSC-derived exosomes enhanced the bacterial phagocytosis capability of the monocytes in severe bacterial pneumonia (Monsel et al., 2015) and enteric infections (Islam et al., 2001). Moreover, immunoregulatory properties of monocytes and decrease in inflammatory cytokine secretion were observed after use of the exosomes (Monsel et al., 2015). There is evidence that MSC-derived exosomes with their immunomodulatory, pro-angiogenesis, and anti-inflammatory activities can prevent inflammatory responses and alleviate COVID-19-induced pneumonia and lung injury (Raghav et al., 2021). In sum, these evidences about the role of exosomes in infections, especially their effects in increase of phagocytosis by monocytes, generate promising reasons to give them a potential property for eradication of the micro-organisms.

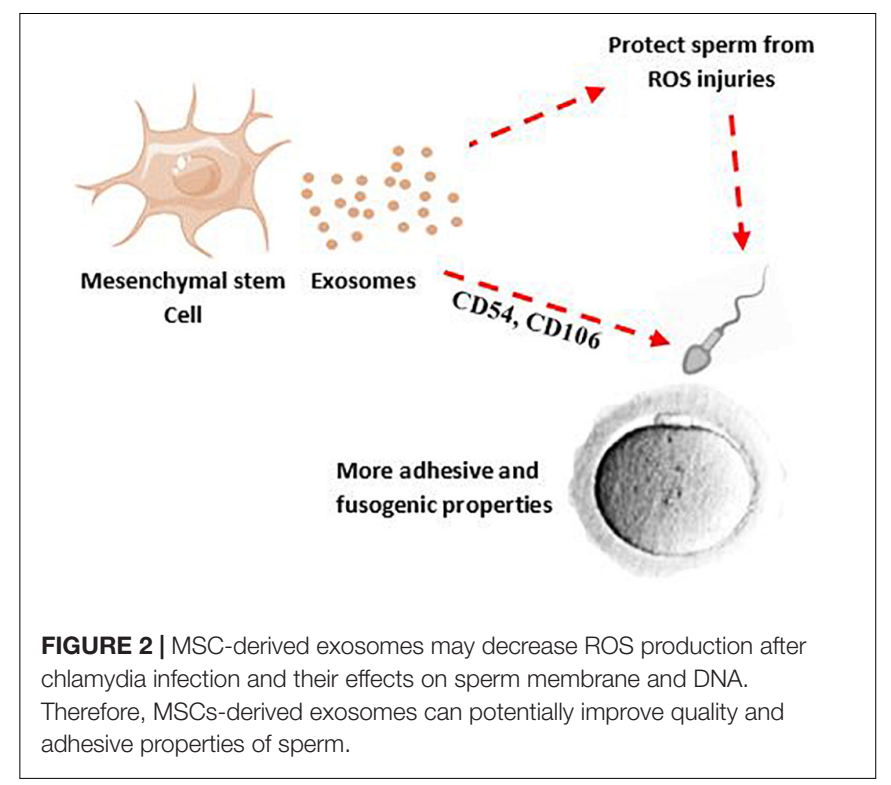

MSC-derived exosomes, as a natural carrier, possess a capability of embedding and delivering antibiotics and drugs. The use of exosomes as carriers leads to reduction of drugs that metabolize, targeted drug delivery, and thus overcome drug resistance (Bartolini et al., 2013; Yeo et al., 2013; Batrakova and Kim, 2015; Gao et al., 2018; Oves et al., 2018; Herrmann et al., 2021). However, exosome modifications change the functions and therapeutic effects of these vehicles (Ma et al., 2017; Tamura et al., 2017).

\section{POTENTIAL THERAPEUTIC ROLE OF MESENCHYMAL STEM CELLS-DERIVED EXOSOME IN SPERM ABNORMALITY}

To achieve proper male fertility, safe sperm manipulation is important. Recently, new methods such as the use of nanoparticles have been used to develop non-invasive techniques for treating and manipulating sperm (Feugang, 2017). The effectiveness and non-invasiveness of the nanoparticles such as exosome for mammalian sperm have been proven (VilanovaPerez et al., 2020). According to animal studies, exosomes appear to be a promising avenue to restore spermatogenesis and sperm regeneration; a study has shown that amniotic fluid-derived exosome can restore sperm parameters such as motility, concentration, as well as the number of spermatogonia, spermatocytes, and ultimately male fertility (Mobarak et al., 2021). The protective effect of exosomes against sperm cryoinjuries (such as cell membrane injury, DNA damage) and oxidative stress produced by cryopreservation process and improvement of the post-thaw sperm parameters has been reported (Qamar et al., 2019; Mahiddine et al., 2020). Interestingly, treatment of spermatozoa with MSC-derived exosomes, in addition to improving sperm parameters after frozen-thawed, can increase sperm adhesive and fusogenic properties by adhesion molecules shuttling such as CD44, CD29, CD54, and CD106 (Mokarizadeh et al., 2013; Figure 2). 
Exosomes contain different molecules such as RNAs that can be incorporated into immune or host cells. RNA sequencing analysis showed that microRNAs were the most frequent in exosomes (Huang et al., 2013). MSC-exosomes can play a role in injury repair and preventing apoptosis after injury through the miRNAs (e.g., miR-19a, miR-144, and miR-21$5 \mathrm{p})$. The potential role of the miRNAs in improvement of chlamydial-induced sperm damages may confer a therapeutic application to the exosome. In addition, there are several clinical trials that demonstrated loading of exosomes with drugs or bioactive molecules (NCT01294072, NCT03608631, NCT01159288) for therapeutic proposes (NCT04602442, NCT04213248, NCT03437759, NCT04276987) (Herrmann et al., 2021). Therefore, it seems that exosomes can be used for treatment of sperm damage.

\section{CONCLUSION}

There are reported evidences demonstrated regenerative, antimicrobial, and anti-inflammatory and anti-oxidant activities of exosomes. It is worthwhile to investigate and challenge the

\section{REFERENCES}

Aalberts, M., van Dissel-Emiliani, F. M. F., van Adrichem, N. P. H., van Wijnen, M., Wauben, M. H. M., Stout, T. A. E., et al. (2012). Identification of distinct populations of prostasomes that differentially express prostate stem cell antigen, annexin A1, and GLIPR2 in humans. Biol. Reprod. 86:82. doi: 10.1095/biolreprod.111.095760

Admyre, C., Johansson, S. M., Qazi, K. R., Filén, J.-J., Lahesmaa, R., Norman, M., et al. (2007). Exosomes with immune modulatory features are present in human breast milk. J. Immunol. 179, 1969-1978. doi: 10.4049/jimmunol.179.3.1969

Aitken, R. J., and West, K. M. (1990). Analysis of the relationship between reactive oxygen species production and leucocyte infiltration in fractions of human semen separated on Percoll gradients. Int. J. Androl. 13, 433-451. doi: 10.1111/ j.1365-2605.1990.tb01051.x

Akyash, F., Javidpou, M., Yazd, E. F., Golzadeh, J., Hajizadeh-Tafti, F., Aflatoonian, R., et al. (2020). Characteristics of the human endometrial regeneration cells as a potential source for future stem cell-based therapies: a lab resources study. Int. J. Reprod. Biomed. 18:943. doi: 10.18502/ijrm.v13i11.7961

Al-mously, N., and Eley, A. (2007). Interaction of Chlamydia trachomatis serovar $\mathrm{E}$ with male genital tract epithelium results in secretion of proinflammatory cytokines Printed in Great Britain. J. Med. Microbiol. 56(Pt 8), 1025-1032. doi: 10.1099/jmm.0.47241-0

Alcayaga-Miranda, F., Cuenca, J., and Khoury, M. (2017). Antimicrobial activity of mesenchymal stem cells: current status and new perspectives of antimicrobial peptide-based therapies. Front. Immunol. 8:339.

Allen, R. C., and Stephens, J. T. Jr. (2011). Myeloperoxidase selectively binds and selectively kills microbes. Infect. Immun. 79, 474-485. doi: 10.1128/IAI.00 910-09

Anderson, D. J., and Hill, J. A. (1988). Cell-mediated immunity in infertility. Am. J. Reprod. Immunol. Microbiol. 17, 22-30. doi: 10.1111/j.1600-0897.1988.tb0 0197.x

Andre, F., Schartz, N. E. C., Movassagh, M., Flament, C., Pautier, P., Morice, P., et al. (2002). Malignant effusions and immunogenic tumour-derived exosomes. Lancet 360, 295-305. doi: 10.1016/S0140-6736(02)09552-1

Arienti, G., Carlini, E., Nicolucci, A., Cosmi, E. V., Santi, F., and Palmerini, C. A. (1999). The motility of human spermatozoa as influenced by prostasomes at various pH levels. Biol. Cell 91, 51-54. doi: 10.1111/j.1768-322X.1999.tb01083.x

Asea, A., Jean-Pierre, C., Kaur, P., Rao, P., Linhares, I. M., Skupski, D., et al. (2008). Heat shock protein-containing exosomes in mid-trimester amniotic fluids. J. Reprod. Immunol. 79, 12-17. doi: 10.1016/j.jri.2008.06.001 identity and effectiveness of the exosomes in the treatment and control of the consequences of male genitalia tract infections, especially chlamydia. MSC-derived exosomes therapy can lend itself as the potential treatment of male infertility caused by microbial infections in the near future.

\section{AUTHOR CONTRIBUTIONS}

MI: study design, investigation, and writing original draft. LD: validation of data and revising the manuscript. MR and MZ: helping on writing the manuscript. SM: validation of data. AA: helping on writing the first draft of the manuscript. BA: supervisor, validation of data, and revising the final version of the manuscript. All authors contributed to the article and approved the submitted version.

\section{ACKNOWLEDGMENTS}

We thank to Dr. Ali Mohammad Abdoli for the managing of all librarian programs in the Yazd Reproductive Sciences Institute.

Bai, S., Li, Y., Wan, Y., Guo, T., Jin, Q., Liu, R., et al. (2021). Sexually transmitted infections and semen quality from subfertile men with and without leukocytospermia. Reprod. Biol. Endocrinol. 19, 1-8. doi: 10.1186/s12958-02100769-2

Balaj, L., Lessard, R., Dai, L., Cho, Y.-J., Pomeroy, S. L., Breakefield, X. O., et al. (2011). Tumour microvesicles contain retrotransposon elements and amplified oncogene sequences. Nat. Commun. 2, 1-9. doi: 10.1038/ncomms 1180

Bartolini, E., Ianni, E., Frigimelica, E., Petracca, R., Galli, G., Berlanda Scorza, F., et al. (2013). Recombinant outer membrane vesicles carrying Chlamydia muridarum HtrA induce antibodies that neutralize Chlamydial infection in vitro. J. Extracell. vesicles 2, 20181. doi: 10.3402/jev.v2i0.20181

Batrakova, E. V., and Kim, M. S. (2015). Using exosomes, naturally-equipped nanocarriers, for drug delivery. J. Control. Release 219, 396-405. doi: 10.1016/j. jconrel.2015.07.030

Beyer, C., and Pisetsky, D. S. (2010). The role of microparticles in the pathogenesis of rheumatic diseases. Nat. Rev. Rheumatol. 6, 21-29. doi: 10.1038/nrrheum. 2009.229

Bezold, G., Politch, J. A., Kiviat, N. B., Kuypers, J. M., Wolff, H., and Anderson, D. J. (2007). Prevalence of sexually transmissible pathogens in semen from asymptomatic male infertility patients with and without leukocytospermia. Fertil. Steril. 87, 1087-1097. doi: 10.1016/j.fertnstert.2006.08.109

Bhatnagar, S., Shinagawa, K., Castellino, F. J., and Schorey, J. S. (2007). Exosomes released from macrophages infected with intracellular pathogens stimulate a proinflammatory response in vitro and in vivo. Blood J. Am. Soc. Hematol. 110, 3234-3244. doi: 10.1182/blood-2007-03-079152

Blanc, L., De Gassart, A., Géminard, C., Bette-Bobillo, P., and Vidal, M. (2005). Exosome release by reticulocytes - an integral part of the red blood cell differentiation system. Blood Cells, Mol. Dis. 35, 21-26. doi: 10.1016/j.bcmd. 2005.04.008

Bryan, E. R., McLachlan, R. I., Rombauts, L., Katz, D. J., Yazdani, A., Bogoevski, K., et al. (2019). Detection of Chlamydia infection within human testicular biopsies. Hum. Reprod. 34, 1891-1898. doi: 10.1093/humrep/dez169

Caby, M.-P., Lankar, D., Vincendeau-Scherrer, C., Raposo, G., and Bonnerot, C. (2005). Exosomal-like vesicles are present in human blood plasma. Int. Immunol. 17, 879-887. doi: 10.1093/intimm/dxh267

Cain, T. K., and Rank, R. G. (1995). Local Th1-like responses are induced by intravaginal infection of mice with the mouse pneumonitis biovar of Chlamydia trachomatis. Infect. Immun. 63, 1784-1789. doi: 10.1128/iai.63.5.1784-1789. 1995 
Centers for Disease Control and Prevention (1998a). In Guidelines for Treatment of Sexually Transmitted Diseases. New York, NY: International Medical Publishing, Incorporated.Inc.

Centers for Disease Control and Prevention (1998b). 1998 Guidelines for Treatment of Sexually Transmitted Diseases. New York, NY: International Medical Publishing, Incorporated.Inc.

Chang, C.-L., Sung, P.-H., Chen, K.-H., Shao, P.-L., Yang, C.-C., Cheng, B.-C., et al. (2018). Adipose-derived mesenchymal stem cell-derived exosomes alleviate overwhelming systemic inflammatory reaction and organ damage and improve outcome in rat sepsis syndrome. Am. J. Transl. Res. 10:1053.

Charrin, S., Jouannet, S., Boucheix, C., and Rubinstein, E. (2014). Tetraspanins at a glance. J. Cell Sci. 127, 3641-3648. doi: 10.1242/jcs.154906

Cheng, L., Zhang, K., Wu, S., Cui, M., and Xu, T. (2017). Focus on mesenchymal stem cell-derived exosomes: opportunities and challenges in cell-free therapy. Stem Cells Int. 2017, 6305295. doi: 10.1155/2017/6305295

Clayton, A., Turkes, A., Navabi, H., Mason, M. D., and Tabi, Z. (2005). Induction of heat shock proteins in B-cell exosomes. J. Cell Sci. 118, 3631-3638. doi: $10.1242 /$ jcs. 02494

Colombo, M., Raposo, G., and Théry, C. (2014). Biogenesis, secretion, and intercellular interactions of exosomes and other extracellular vesicles. Annu. Rev. Cell Dev. Biol. 30, 255-289. doi: 10.1146/annurev-cellbio-101512122326

Cortés-Araya, Y., Amilon, K., Rink, B. E., Black, G., Lisowski, Z., Donadeu, F. X., et al. (2018). Comparison of antibacterial and immunological properties of mesenchymal stem/stromal cells from equine bone marrow, endometrium, and adipose tissue. Stem Cells Dev. 27, 1518-1525. doi: 10.1089/scd.2017.0241

Crenshaw, B. J., Sims, B., and Matthews, Q. L. (2018). "Biological function of exosomes as diagnostic markers and therapeutic delivery vehicles in carcinogenesis and infectious diseases," in Nanomedicines, ed. M. A. Farrukh (London: IntechOpen).

Dehghan Marvast, L., Aflatoonian, A., Talebi, A. R., Eley, A., and Pacey, A. A. (2017). Relationship between Chlamydia trachomatis and Mycoplasma genitalium infection and pregnancy rate and outcome in Iranian infertile couples. Andrologia 49:e12747. doi: 10.1111/and.12747

Dehghan Marvast, L., Aflatoonian, A., Talebi, A. R., Ghasemzadeh, J., and Pacey, A. A. (2016). Semen inflammatory markers and Chlamydia trachomatis infection in male partners of infertile couples. Andrologia 48, 729-736. doi: 10.1111/and.12501

Dehghan Marvast, L., Talebi, A. R., Ghasemzadeh, J., Hosseini, A., and Pacey, A. A. (2018). Effects of Chlamydia trachomatis infection on sperm chromatin condensation and DNA integrity. Andrologia 50:e12918. doi: 10.1111/and. 12918

Deng, H., Wu, L., Liu, M., Zhu, L., Chen, Y., Zhou, H., et al. (2020). Bone marrow mesenchymal stem cell-derived exosomes attenuate LPSinduced ARDS by modulating macrophage polarization through inhibiting glycolysis in macrophages. Shock 54, 828-843. doi: 10.1097/SHK.00000000000 01549

Dieterle, S. (2008). Urogenital infections in reproductive medicine. Andrologia 40, 117-119. doi: 10.1111/j.1439-0272.2008.00833.x

Dohle, G. R. (2003). Inflammatory-associated obstructions of the male reproductive tract. Andrologia 35, 321-324.

Dohle, G. R., Weidner, W., Jungwirth, A., Colpi, G., Papp, G., Pomerol, J., et al. (2004). Guidelines on Male Infertility. Arnhem: European Association of Urology.

Eley, A., Pacey, A. A., Galdiero, M. M., Galdiero, M. M., and Galdiero, F. (2005). Can Chlamydia trachomatis directly damage your sperm? Lancet Infect. Dis. 5, 53-57. doi: 10.1016/S1473-3099(04)01254-X

Fabiani, R., Johansson, L., Lundkvist, O., and Ronquist, G. (1994). Enhanced recruitment of motile spermatozoa by prostasome inclusion in swim-up medium. Hum. Reprod. 9, 1485-1489. doi: 10.1093/oxfordjournals.humrep. a138735

Fang, S., Xu, C., Zhang, Y., Xue, C., Yang, C., Bi, H., et al. (2016). Umbilical cord-derived mesenchymal stem cell-derived exosomal microRNAs suppress myofibroblast differentiation by inhibiting the transforming growth factorB/SMAD2 pathway during wound healing. Stem Cells Transl. Med. 5, 14251439. doi: $10.5966 /$ sctm.2015-0367

Feugang, J. M. (2017). Novel agents for sperm purification, sorting, and imaging. Mol. Reprod. Dev. 84, 832-841. doi: 10.1002/mrd.22831
Février, B., and Raposo, G. (2004). Exosomes: endosomal-derived vesicles shipping extracellular messages. Curr. Opin. Cell Biol. 16, 415-421. doi: 10.1016/j.ceb. 2004.06.003

François, S., Bensidhoum, M., Mouiseddine, M., Mazurier, C., Allenet, B., Semont, A., et al. (2006). Local irradiation not only induces homing of human mesenchymal stem cells at exposed sites but promotes their widespread engraftment to multiple organs: a study of their quantitative distribution after irradiation damage. Stem Cells 24, 1020-1029. doi: 10.1634/stemcells.20050260

Fu, M., Gu, J., Jiang, P., Qian, H., Xu, W., and Zhang, X. (2019). Exosomes in gastric cancer: roles, mechanisms, and applications. Mol. Cancer 18, 1-12. doi: 10.1186/s12943-019-1001-7

Gallegos, G., Ramos, B., Santiso, R., Goyanes, V., Gosálvez, J., and Fernández, J. L. (2008). Sperm DNA fragmentation in infertile men with genitourinary infection by Chlamydia trachomatis and Mycoplasma. Fertil. Steril. 90, 328-334.

Gao, F., Xu, L., Yang, B., Fan, F., and Yang, L. (2018). Kill the real with the fake: eliminate intracellular Staphylococcus aureus using nanoparticle coated with its extracellular vesicle membrane as active-targeting drug carrier. ACS Infect. Dis. 5, 218-227. doi: 10.1021 /acsinfecdis.8b00212

Geisler, W. M. (2010). Duration of untreated, uncomplicated Chlamydia trachomatis genital infection and factors associated with Chlamydia resolution: a review of human studies. J. Infect. Dis. 201, S104-S113. doi: 10.1086/ 652402

Gläser, R., Harder, J., Lange, H., Bartels, J., Christophers, E., and Schröder, J.-M. (2005). Antimicrobial psoriasin (S100A7) protects human skin from Escherichia coli infection. Nat. Immunol. 6, 57-64. doi: 10.1038/ni1142

Gonzales, P. A., Zhou, H., Pisitkun, T., Wang, N. S., Star, R. A., Knepper, M. A., et al. (2010). "Isolation and purification of exosomes in urine," in The Urinary Proteome. Methods in Molecular Biology (Methods and Protocols), Vol. 641, ed. A. Rai (New York, NY: Humana Press), 89-99. doi: 10.1007/978-1-60761711-2_6

Gould, S. J., and Raposo, G. (2013). As we wait: coping with an imperfect nomenclature for extracellular vesicles. J. Extracell. Vesicles 2:20389. doi: 10. 3402/jev.v2i0.20389

Grant, R., Ansa-Addo, E., Stratton, D., Antwi-Baffour, S., Jorfi, S., Kholia, S., et al. (2011). A filtration-based protocol to isolate human plasma membrane-derived vesicles and exosomes from blood plasma. J. Immunol. Methods 371, 143-151. doi: 10.1016/j.jim.2011.06.024

Greening, D. W., Xu, R., Ji, H., Tauro, B. J., and Simpson, R. J. (2015). "A protocol for exosome isolation and characterization: evaluation of ultracentrifugation, density-gradient separation, and immunoaffinity capture methods," in Proteomic Profiling. Methods in Molecular Biology, Vol. 1295, ed. A. Posch (New York, NY: Humana Press), 179-209. doi: 10.1007/978-1-49392550-6_15

Guescini, M., Guidolin, D., Vallorani, L., Casadei, L., Gioacchini, A. M., Tibollo, P., et al. (2010). C2C12 myoblasts release micro-vesicles containing mtDNA and proteins involved in signal transduction. Exp. Cell Res. 316, 1977-1984. doi: 10.1016/j.yexcr.2010.04.006

György, B., Szabó, T. G., Pásztói, M., Pál, Z., Misják, P., Aradi, B., et al. (2011). Membrane vesicles, current state-of-the-art: emerging role of extracellular vesicles. Cell. Mol. life Sci. 68, 2667-2688. doi: 10.1007/s00018-011-0689-3

Hakimi, H., Zare-Bidaki, M., Zainodini, N., Assar, S., and Arababadi, M. K. (2014). Significant roles played by IL-10 in Chlamydia infections. Inflammation 37, 818-823. doi: 10.1007/s10753-013-9801-1

Hamada, A., Esteves, S. C., and Agarwal, A. (2011). The role of contemporary andrology in unraveling the mystery of unexplained male infertility. Open Reprod. Sci. J. 4, 27-41. doi: 10.2174/1874255601103010027

Hamazah, L. M., and Al-Dahmoshi, H. O. M. (2021). Bacterial Profile and Resistance Patterns of Bacteriospermia among Pyospermic Patients in Hilla City, Iraq. Ann. Rom. Soc. Cell Biol. 25, 332-342.

Han, C., Sun, X., Liu, L., Jiang, H., Shen, Y., Xu, X., et al. (2016). Exosomes and their therapeutic potentials of stem cells. Stem Cells Int. 2016, 7653489. doi: $10.1155 / 2016 / 7653489$

Hao, Q., Gudapati, V., Monsel, A., Park, J. H., Hu, S., Kato, H., et al. (2019). Mesenchymal stem cell-derived extracellular vesicles decrease lung injury in mice. J. Immunol. 203, 1961-1972. doi: 10.4049/jimmunol.1801534

Harman, R. M., Yang, S., He, M. K., and Van de Walle, G. R. (2017). Antimicrobial peptides secreted by equine mesenchymal stromal cells inhibit the growth of 
bacteria commonly found in skin wounds. Stem Cell Res. Ther. 8, 1-14. doi: 10.1186/s13287-017-0610-6

Harrell, C. R., Fellabaum, C., Jovicic, N., Djonov, V., Arsenijevic, N., and Volarevic, V. (2019a). Molecular mechanisms responsible for therapeutic potential of mesenchymal stem cell-derived secretome. Cells 8:467. doi: 10.3390/ cells 8050467

Harrell, C. R., Jovicic, N., Djonov, V., Arsenijevic, N., and Volarevic, V. (2019b). Mesenchymal stem cell-derived exosomes and other extracellular vesicles as new remedies in the therapy of inflammatory diseases. Cells 8:1605. doi: 10 . 3390/cells8121605

Harris, C. L., Vigar, M. A., Rey Nores, J. E., Horejsi, V., Labeta, M. O., and Morgan, B. P. (2001). The lipopolysaccharide co-receptor CD14 is present and functional in seminal plasma and expressed on spermatozoa. Immunology 104, 317-323. doi: $10.1046 / j .1365-2567.2001 .01312 . x$

Henne, W. M., Buchkovich, N. J., and Emr, S. D. (2011). The ESCRT pathway. Dev. Cell 21, 77-91. doi: 10.1016/j.devcel.2011.05.015

Herrmann, I. K., Wood, M. J. A., and Fuhrmann, G. (2021). Extracellular vesicles as a next-generation drug delivery platform. Nat. Nanotechnol. 16, 748-759. doi: 10.1038/s41565-021-00931-2

Hoseini, S. M., Sheikhha, M. H., Kalantar, S. M., Matin, M. M., Aflatoonian, B., Bahrami, A. R., et al. (2020). A comparative analysis of immunomodulatory genes in two clonal subpopulations of CD90+ amniocytes isolated from human amniotic fluid. Placenta 101, 234-241. doi: 10.1016/j.placenta.2020.10.001

Hosseinzadeh, S., Brewis, I. A., Pacey, A. A., Moore, H. D. M., and Eley, A. (2000). Coincubation of human spermatozoa with Chlamydia trachomatis in vitro causes increased tyrosine phosphorylation of sperm proteins. Infect. Immun. 68, 4872-4876. doi: 10.1128/IAI.68.9.4872-4876.2000

Huang, X., Yuan, T., Tschannen, M., Sun, Z., Jacob, H., Du, M., et al. (2013). Characterization of human plasma-derived exosomal RNAs by deep sequencing. BMC Genomics 14:319. doi: 10.1186/1471-2164-14-319

Isaiah, I. N., Nche, B. T., Nwagu, I. G., and Nnanna, I. I. (2011). Current studies on bacterospermia the leading cause of male infertility: a protégé and potential threat towards mans extinction. N. Am. J. Med. Sci. 3:562. doi: 10.4297/ najms

Islam, D., Bandholtz, L., Nilsson, J., Wigzell, H., Christensson, B., Agerberth, B., et al. (2001). Downregulation of bactericidal peptides in enteric infections: a novel immune escape mechanism with bacterial DNA as a potential regulator. Nat. Med. 7, 180-185. doi: 10.1038/84627

Janockova, J., Slovinska, L., Harvanova, D., Spakova, T., and Rosocha, J. (2021). New therapeutic approaches of mesenchymal stem cells-derived exosomes. J. Biomed. Sci. 28, 1-26. doi: 10.1186/s12929-021-00736-4

Javidpou, M., Seifati, S.-M., Farashahi-Yazd, E., Hajizadeh-Tafti, F., Golzadeh, J., Akyash, F., et al. (2021). Mesenchymal stem/stromal-like cells from diploid and triploid human embryonic stem cells display different gene expression profiles. Iran. Biomed. J. 25, 99. doi: 10.29252/ibj.25.2.99

Jeppesen, D. K., Fenix, A. M., Franklin, J. L., Higginbotham, J. N., Zhang, Q., Zimmerman, L. J., et al. (2019). Reassessment of exosome composition. Cell 177, 428-445.e18. doi: 10.1016/j.cell.2019.02.029

Jungwirth, A., Giwercman, A., Tournaye, H., Diemer, T., Kopa, Z., Dohle, G., et al. (2012). European association of urology guidelines on male infertility: the 2012 update. Eur. Urol. 62, 324-332. doi: 10.1016/j.eururo.2012.04.048

Kalluri, R. (2016). The biology and function of exosomes in cancer. J. Clin. Invest. 126, 1208-1215. doi: 10.1172/JCI81135

Keck, C., Gerber-Schäfer, C., Clad, A., Wilhelm, C., and Breckwoldt, M. (1998). Seminal tract infections: impact on male fertility and treatment options. Hum. Reprod. Update 4, 891-903. doi: 10.1093/humupd/4.6.891

Keerthikumar, S., Chisanga, D., Ariyaratne, D., Al Saffar, H., Anand, S., Zhao, K., et al. (2016). ExoCarta: a web-based compendium of exosomal cargo. J. Mol. Biol. 428, 688-692. doi: 10.1016/j.jmb.2015.09.019

Kharazi, U., and Badalzadeh, R. (2020). A review on the stem cell therapy and an introduction to exosomes as a new tool in reproductive medicine. Reprod. Biol. 20, 447-459. doi: 10.1016/j.repbio.2020.07.002

Kong, F. Y. S., Tabrizi, S. N., Law, M., Vodstrcil, L. A., Chen, M., Fairley, C. K., et al. (2014). Azithromycin versus doxycycline for the treatment of genital Chlamydia infection: a meta-analysis of randomized controlled trials. Clin. Infect. Dis. 59, 193-205. doi: 10.1093/cid/ciu220

Kowal, J., Tkach, M., and Théry, C. (2014). Biogenesis and secretion of exosomes. Curr. Opin. Cell Biol. 29, 116-125. doi: 10.1016/j.ceb.2014.05.004
Krasnodembskaya, A., Song, Y., Fang, X., Gupta, N., Serikov, V., Lee, J., et al. (2010). Antibacterial effect of human mesenchymal stem cells is mediated in part from secretion of the antimicrobial peptide LL-37. Stem Cells 28, 2229-2238. doi: 10.1002/stem.544

Lai, E. C. (2004). Notch signaling: control of cell communication and cell fate. Development 131, 965-973. doi: 10.1242/dev.01074

Livshits, M. A., Khomyakova, E., Evtushenko, E. G., Lazarev, V. N., Kulemin, N. A., Semina, S. E., et al. (2015). Isolation of exosomes by differential centrifugation: theoretical analysis of a commonly used protocol. Sci. Rep. 5:17319. doi: 10. 1038/srep17319

Lotti, F., and Maggi, M. (2013). Interleukin 8 and the male genital tract. J. Reprod. Immunol. 100, 54-65. doi: 10.1016/j.jri.2013.02.004

Ma, J., Zhao, Y., Sun, L., Sun, X., Zhao, X., Sun, X., et al. (2017). Exosomes derived from AKt-modified human umbilical cord mesenchymal stem cells improve cardiac regeneration and promote angiogenesis via activating platelet-derived growth factor D. Stem Cells Transl. Med. 6, 51-59. doi: 10.5966/sctm.2016-0038

Ma, Z.-J., Yang, J.-J., Lu, Y.-B., Liu, Z.-Y., and Wang, X.-X. (2020). Mesenchymal stem cell-derived exosomes: Toward cell-free therapeutic strategies in regenerative medicine. World J. Stem Cells 12:814. doi: 10.4252/wjsc.v12.i8.814

Mackern-Oberti, J. P., Motrich, R. D., Breser, M. L., Sánchez, L. R., Cuffini, C., and Rivero, V. E. (2013). Chlamydia trachomatis infection of the male genital tract: an update. J. Reprod. Immunol. 100, 37-53. doi: 10.1016/j.jri.2013.05.002

Mahiddine, F. Y., Qamar, A. Y., and Kim, M. J. (2020). Canine amniotic membrane derived mesenchymal stem cells exosomes addition in canine sperm freezing medium. J. Anim. Reprod. Biotechnol. 35, 268-272. doi: 10.12750/JARB.35. 3.268

Masyuk, A. I., Huang, B. Q., Ward, C. J., Gradilone, S. A., Banales, J. M., Masyuk, T. V., et al. (2010). Biliary exosomes influence cholangiocyte regulatory mechanisms and proliferation through interaction with primary cilia. Am. J. Physiol. Liver Physiol. 299, G990-G999. doi: 10.1152/ajpgi.00093.2010

McAndrews, K. M., and Kalluri, R. (2019). Mechanisms associated with biogenesis of exosomes in cancer. Mol. Cancer 18, 1-11. doi: 10.1186/s12943-019-0963-9

Meldolesi, J. (2018). Exosomes and ectosomes in intercellular communication. Curr. Biol. 28, R435-R444.

Michael, A., Bajracharya, S. D., Yuen, P. S. T., Zhou, H., Star, R. A., Illei, G. G., et al. (2010). Exosomes from human saliva as a source of microRNA biomarkers. Oral Dis. 16, 34-38. doi: 10.1111/j.1601-0825.2009.01604.x

Mishori, R., McClaskey, E. L., and WinklerPrins, V. (2012). Chlamydia trachomatis infections: screening, diagnosis, and management. Am. Fam. Physician 86, $1127-1132$.

Miyake, H., Lee, C., Chusilp, S., Bhalla, M., Li, B., Pitino, M., et al. (2020). Human breast milk exosomes attenuate intestinal damage. Pediatr. Surg. Int. 36, 155-163. doi: 10.1007/s00383-019-04599-7

Mobarak, H., Heidarpour, M., Rahbarghazi, R., Nouri, M., and Mahdipour, M. (2021). Amniotic fluid-derived exosomes improved spermatogenesis in a rat model of azoospermia. Life Sci. 274:119336. doi: 10.1016/j.lfs.2021.119336

Mokarizadeh, A., Rezvanfar, M.-A., Dorostkar, K., and Abdollahi, M. (2013). Mesenchymal stem cell derived microvesicles: trophic shuttles for enhancement of sperm quality parameters. Reprod. Toxicol. 42, 78-84. doi: 10.1016/j.reprotox. 2013.07.024

Monsel, A., Zhu, Y., Gennai, S., Hao, Q., Hu, S., Rouby, J.-J., et al. (2015). Therapeutic effects of human mesenchymal stem cell-derived microvesicles in severe pneumonia in mice. Am. J. Respir. Crit. Care Med. 192, 324-336. doi: $10.1164 / \mathrm{rccm} .201410-1765 \mathrm{OC}$

Murray, S. M., and McKay, P. F. (2021). Chlamydia trachomatis: cell biology, immunology and vaccination. Vaccine 39, 2965-2975. doi: 10.1016/j.vaccine. 2021.03.043

Navabi, H., Croston, D., Hobot, J., Clayton, A., Zitvogel, L., Jasani, B., et al. (2005). Preparation of human ovarian cancer ascites-derived exosomes for a clinical trial. Blood Cells, Mol. Dis. 35, 149-152. doi: 10.1016/j.bcmd.2005.06.008

Nieschlag, E., Behre, H. M., and Nieschlag, S. (1997). Andrology. Berlin: Springer.

Nolte-'t Hoen, E. N. M., Buschow, S. I, Anderton, S. M., Stoorvogel, W., and Wauben, M. H. M. (2009). Activated T cells recruit exosomes secreted by dendritic cells via LFA-1. Blood. J. Am. Soc. Hematol. 113, 1977-1981. doi: 10.1182/blood-2008-08-174094

Ogawa, Y., Kanai-Azuma, M., Akimoto, Y., Kawakami, H., and Yanoshita, R. (2008). Exosome-like vesicles with dipeptidyl peptidase IV in human saliva. Biol. Pharm. Bull. 31, 1059-1062. doi: 10.1248/bpb.31.1059 
Ombelet, W., Cooke, I., Dyer, S., Serour, G., and Devroey, P. (2008). Infertility and the provision of infertility medical services in developing countries. Hum. Reprod. Update 14, 605-621. doi: 10.1093/humupd/dmn042

Omsland, A., Sager, J., Nair, V., Sturdevant, D. E., and Hackstadt, T. (2012). Developmental stage-specific metabolic and transcriptional activity of Chlamydia trachomatis in an axenic medium. Proc. Natl. Acad. Sci.U.S.A. 109, 19781-19785. doi: 10.1073/pnas.1212831109

World Health Organization (2016). Global Health Sector Strategy on Sexually Transmitted Infections 2016-2021: Toward Ending STIs. Geneva: World Health Organization.

Oves, M., Qari, H. A., Felemban, N. M., Khan, A. A. P., Rehan, M., Tabrez, S., et al. (2018). Exosomes: a paradigm in drug development against cancer and infectious diseases. J. Nanomater. 2018:6895464. doi: 10.1155/2018/689546

Paavonen, J., and Eggert-Kruse, W. (1999). Chlamydia trachomatis: impact on human reproduction. Hum. Reprod. Update 5, 433-447. doi: 10.1093/humupd/ 5.5 .433

Pacey, A. A., and Eley, A. (2004). Chlamydia trachomatis and male fertility. Hum. Fertil. 7, 271-276. doi: 10.1080/14647270400016373

Park, K.-H., Kim, B.-J., Kang, J., Nam, T.-S., Lim, J. M., Kim, H. T., et al. (2011). $\mathrm{Ca} 2+$ signaling tools acquired from prostasomes are required for progesteroneinduced sperm motility. Sci. Signal. 4:ra31. doi: 10.1126/scisignal.2001595

Parolini, I., Federici, C., Raggi, C., Lugini, L., Palleschi, S., De Milito, A., et al. (2009). Microenvironmental $\mathrm{pH}$ is a key factor for exosome traffic in tumor cells. J. Biol. Chem. 284, 34211-34222. doi: 10.1074/jbc.M109.041152

Patton, D. L., Teng, A., Randall, A., Liang, X., Felgner, P. L., and Luis, M. (2014). Whole genome identification of $C$. trachomatis immunodominant antigens after genital tract infections and effect of antibiotic treatment of pigtailed macaques. J. Proteomics 108, 99-109. doi: 10.1016/j.jprot.2014.05.009

Perry, L. L., Feilzer, K., and Caldwell, H. D. (1997). Immunity to Chlamydia trachomatis is mediated by $\mathrm{T}$ helper 1 cells through IFN-gamma-dependent and-independent pathways. J. Immunol. 158, 3344-3352.

Peterson, M. F., Otoc, N., Sethi, J. K., Gupta, A., and Antes, T. J. (2015). Integrated systems for exosome investigation. Methods 87, 31-45. doi: 10.1016/j.ymeth. 2015.04.015

Phinney, D. G., and Pittenger, M. F. (2017). Concise review: MSC-derived exosomes for cell-free therapy. Stem Cells 35, 851-858. doi: 10.1002/stem.2575

Qamar, A. Y., Fang, X., Kim, M. J., and Cho, J. (2019). Improved post-thaw quality of canine semen after treatment with exosomes from conditioned medium of adipose-derived mesenchymal stem cells. Animals 9:865. doi: 10 . 3390/ani9110865

Qin, W., Tsukasaki, Y., Dasgupta, S., Mukhopadhyay, N., Ikebe, M., and Sauter, E. R. (2016). Exosomes in human breast milk promote EMT. Clin. Cancer Res. 22, 4517-4524. doi: 10.1158/1078-0432.CCR-16-0135

Raghav, A., Khan, Z. A., Upadhayay, V. K., Tripathi, P., Gautam, K. A., Mishra, B. K., et al. (2021). Mesenchymal stem cell-derived exosomes exhibit promising potential for treating SARS-CoV-2-infected patients. Cells 10:587. doi: 10.3390/ cells 10030587

Ramos, T. L., Sánchez-Abarca, L. I., Muntión, S., Preciado, S., Puig, N., LópezRuano, G., et al. (2016). MSC surface markers (CD44, CD73, and CD90) can identify human MSC-derived extracellular vesicles by conventional flow cytometry. Cell Commun. Signal. 14, 1-14. doi: 10.1186/s12964-015-0124-8

Rana, K., Vander, H., Bhandari, P., Thaper, D., and Prabha, V. (2016). Microorganisms and male infertility: possible pathophysiological mechanisms. Adv. Clin. Med. Microbiol. 1:002.

Redgrove, K. A., and McLaughlin, E. A. (2014). The role of the immune response in Chlamydia trachomatis infection of the male genital tract: a double-edged sword. Front. Immunol. 5:534. doi: 10.3389/fimmu.2014.00534

Runz, S., Keller, S., Rupp, C., Stoeck, A., Issa, Y., Koensgen, D., et al. (2007). Malignant ascites-derived exosomes of ovarian carcinoma patients contain CD24 and EpCAM. Gynecol. Oncol. 107, 563-571. doi: 10.1016/j.ygyno.2007. 08.064

Sagredo, A., Sepulveda, S., Roa, J. C., and Oróstica, L. (2017). Exosomes in bile as potential pancreatobiliary tumor biomarkers. Transl. Cancer Res. 6, S1371-S1383. doi: 10.21037/tcr.2017.10.37

Salek, F., Baharara, J., Nejad, K., and Amini, E. (2021). Theriogenology The guardians of germ cells; sertoli-derived exosomes against electromagnetic fi eldinduced oxidative stress in mouse spermatogonial stem cells. Theriogenology 173, 112-122. doi: 10.1016/j.theriogenology.2021.08.001
Sanocka-Maciejewska, D., Ciupińska, M., and Kurpisz, M. (2005). Bacterial infection and semen quality. J. Reprod. Immunol. 67, 51-56. doi: 10.1016/j.jri. 2005.06.003

Satta, A., Stivala, A., Garozzo, A., Morello, A., Perdichizzi, A., Vicari, E., et al. (2006). Experimental Chlamydia trachomatis infection causes apoptosis in human sperm. Hum. Reprod. 21, 134-137. doi: 10.1093/humrep/dei269

Sellami, H., Gdoura, R., Mabrouk, I., Frikha-Gargouri, O., Keskes, L., Mallek, Z., et al. (2011). A proposed mouse model to study male infertility provoked by genital serovar E, Chlamydia trachomatis. J. Androl. 32, 86-94. doi: 10.2164/ jandrol.109.009183

Sellami, H., Znazen, A., Sellami, A., Mnif, H., Louati, N., Ben Zarrouk, S., et al. (2014). Molecular detection of Chlamydia trachomatis and other sexually transmitted bacteria in semen of male partners of infertile couples in Tunisia: the effect on semen parameters and spermatozoa apoptosis markers. PLoS One 9:e98903. doi: 10.1371/journal.pone.0098903

Shabbir, A., Cox, A., Rodriguez-Menocal, L., Salgado, M., and Van Badiavas, E. (2015). Mesenchymal stem cell exosomes induce proliferation and migration of normal and chronic wound fibroblasts, and enhance angiogenesis in vitro. Stem Cells Dev. 24, 1635-1647. doi: 10.1089/scd.2014.0316

Sharma, R. K., and Agarwal, A. (1996). Role of reactive oxygen species in male infertility. Urology 48, 835-850. doi: 10.1016/s0090-4295(96)00313-5

Shurtleff, M. J., Yao, J., Qin, Y., Nottingham, R. M., Temoche-Diaz, M. M., Schekman, R., et al. (2017). Broad role for YBX1 in defining the small noncoding RNA composition of exosomes. Proc. Natl. Acad. Sci.U.S.A. 114, E8987-E8995. doi: 10.1073/pnas.1712108114

Simpson, R. J., Jensen, S. S., and Lim, J. W. E. (2008). Proteomic profiling of exosomes: current perspectives. Proteomics 8, 4083-4099.

Skogberg, G., Lundberg, V., Berglund, M., Gudmundsdottir, J., Telemo, E., Lindgren, S., et al. (2015). Human thymic epithelial primary cells produce exosomes carrying tissue-restricted antigens. Immunol. Cell Biol. 93, 727-734. doi: 10.1038/icb.2015.33

Skotland, T., Hessvik, N. P., Sandvig, K., and Llorente, A. (2019). Exosomal lipid composition and the role of ether lipids and phosphoinositides in exosome biology. J. Lipid Res. 60, 9-18. doi: 10.1194/jlr.R084343

Song, J., Chen, X., Wang, M., Xing, Y., Zheng, Z., and Hu, S. (2014). Cardiac endothelial cell-derived exosomes induce specific regulatory B cells. Sci. Rep. 4:7583. doi: 10.1038/srep07583

Song, J. P., Chen, X., Wang, M. Y., Xing, Y., Zheng, Z., and Hu, S. S. (2015). "Cardiac endothellial cell-derived exosomes induce specific regulatory b cell," in Cardiology 10, CH-4009, (Basel: Karger Allschwilerstrasse), 383.

Squadrito, M. L., Baer, C., Burdet, F., Maderna, C., Gilfillan, G. D., Lyle, R., et al. (2014). Endogenous RNAs modulate microRNA sorting to exosomes and transfer to acceptor cells. Cell Rep. 8, 1432-1446. doi: 10.1016/j.celrep.2014. 07.035

Stamm, W. E., Hicks, C. B., Martin, D. H., Leone, P., Hook, E. W., Cooper, R. H., et al. (1995). Azithromycin for empirical treatment of the nongonococcal urethritis syndrome in men: a randomized double-blind study. JAMA 274, 545-549.

Stoorvogel, W., Kleijmeer, M. J., Geuze, H. J., and Raposo, G. (2002). The biogenesis and functions of exosomes. Traffic 3, 321-330. doi: 10.1034/j.16000854.2002.30502.x

Street, J. M., Koritzinsky, E. H., Glispie, D. M., and Yuen, P. S. T. (2017). "Urine exosome isolation and characterization," in Drug Safety Evaluation. Methods in Molecular Biology, Vol. 1641, ed. J. C. Gautier (New York, NY: Humana Press), 413-423.

Sun, B., Ma, Y., Wang, F., Hu, L., and Sun, Y. (2019). miR-644-5p carried by bone mesenchymal stem cell-derived exosomes targets regulation of p53 to inhibit ovarian granulosa cell apoptosis. Stem Cell Res. Ther. 10, 1-9. doi: 10.1186/ s13287-019-1442-3

Tamura, R., Uemoto, S., and Tabata, Y. (2017). Augmented liver targeting of exosomes by surface modification with cationized pullulan. Acta Biomater. 57, 274-284. doi: 10.1016/j.actbio.2017.05.013

Tang, Y., Zhou, Y., and Li, H.-J. (2021). Advances in mesenchymal stem cell exosomes: a review. Stem Cell Res. Ther. 12, 1-12. doi: 10.1186/s13287-02102138-7

Taylor, D. D., and Shah, S. (2015). Methods of isolating extracellular vesicles impact down-stream analyses of their cargoes. Methods 87, 3-10. doi: 10.1016/j.ymeth. 2015.02.019 
Thakur, B. K., Zhang, H., Becker, A., Matei, I., Huang, Y., Costa-Silva, B., et al. (2014). Double-stranded DNA in exosomes: a novel biomarker in cancer detection. Cell Res. 24, 766-769. doi: 10.1038/cr.2014.44

Théry, C., Witwer, K. W., Aikawa, E., Alcaraz, M. J., Anderson, J. D., Andriantsitohaina, R., et al. (2018). Minimal information for studies of extracellular vesicles 2018 (MISEV2018): a position statement of the International Society for Extracellular Vesicles and update of the MISEV2014 guidelines. J. Extracell. Vesicles 7, 1535750. doi: 10.1080/20013078.2018. 1535750

Trajkovic, K., Hsu, C., Chiantia, S., Rajendran, L., Wenzel, D., Wieland, F., et al. (2008). Ceramide triggers budding of exosome vesicles into multivesicular endosomes. Science 319, 1244-1247. doi: 10.1126/science.1153124

Urbanelli, L., Magini, A., Buratta, S., Brozzi, A., Sagini, K., Polchi, A., et al. (2013). Signaling pathways in exosomes biogenesis, secretion and fate. Genes (Basel) 4, 152-170. doi: 10.3390/genes4020152

Valadi, H., Ekström, K., Bossios, A., Sjöstrand, M., Lee, J. J., and Lötvall, J. O. (2007). Exosome-mediated transfer of mRNAs and microRNAs is a novel mechanism of genetic exchange between cells. Nat. Cell Biol. 9, 654-659.

van Balkom, B. W. M., Gremmels, H., Giebel, B., and Lim, S. K. (2019). Proteomic signature of mesenchymal stromal cell-derived small extracellular vesicles. Proteomics 19, 1800163. doi: 10.1002/pmic.201800163

Van Niel, G., Charrin, S., Simoes, S., Romao, M., Rochin, L., Saftig, P., et al. (2011). The tetraspanin CD63 regulates ESCRT-independent and-dependent endosomal sorting during melanogenesis. Dev. Cell 21, 708-721. doi: 10.1016/j. devcel.2011.08.019

Vanić, Ž, Jøraholmen, M. W., and Škalko-Basnet, N. (2021). Nanomedicines for the topical treatment of vulvovaginal infections: addressing the challenges of antimicrobial resistance. Adv. Drug Deliv. Rev. 178:113855. doi: 10.1016/j.addr. 2021.113855

Veznik, Z., Pospisil, L., Svecova, D., Zajicova, A., and Unzeitig, V. (2004). Chlamydiae in the ejaculate: their influence on the quality and morphology of sperm. Acta Obstet. Gynecol. Scand. 83, 656-660. doi: 10.1111/j.0001-6349. 2004.00542.x

Vilanova-Perez, T., Jones, C., Balint, S., Dragovic, R., Dustin, L. M., Yeste, M., et al. (2020). Exosomes derived from HEK293T cells interact in an efficient and noninvasive manner with mammalian sperm in vitro. Nanomedicine 15 , 1965-1980. doi: 10.2217/nnm-2020-0056

Vojtech, L., Woo, S., Hughes, S., Levy, C., Ballweber, L., Sauteraud, R. P., et al. (2014). Exosomes in human semen carry a distinctive repertoire of small non-coding RNAs with potential regulatory functions. Nucleic Acids Res. 42, 7290-7304. doi: 10.1093/nar/gku347

Wang, J., Sun, X., Zhao, J., Yang, Y., Cai, X., Xu, J., et al. (2017). Exosomes: a novel strategy for treatment and prevention of diseases. Front. Pharmacol. 8:300. doi: 10.3389/fphar.2017.00300

Li, J. W., Wei, L., Han, Z., and Chen, Z. (2019). Mesenchymal stromal cells-derived exosomes alleviate ischemia/reperfusion injury in mouse lung by transporting anti-apoptotic miR-21-5p. . Eur. J. Pharmacol. 852, 68-76. doi: 10.1016/j.ejphar. 2019.01.022

Wei, Z., Qiao, S., Zhao, J., Liu, Y., Li, Q., Wei, Z., et al. (2019). miRNA181a over-expression in mesenchymal stem cell-derived exosomes influenced inflammatory response after myocardial ischemia-reperfusion injury. Life Sci. 232:116632. doi: 10.1016/j.lfs.2019.116632

Wen, Z., Mai, Z., Zhu, X., Wu, T., Chen, Y., Geng, D., et al. (2020). Mesenchymal stem cell-derived exosomes ameliorate cardiomyocyte apoptosis in hypoxic conditions through microRNA144 by targeting the PTEN/AKT pathway. Stem Cell Res. Ther. 11, 1-17. doi: 10.1186/s13287-020-1563-8

Workowski, K. A., and Berman, S. M. (2011). Centers for Disease Control and Prevention sexually transmitted disease treatment guidelines. Clin. Infect. Dis. 53 , S59-S63.

Xunian, Z., and Kalluri, R. (2020). Biology and therapeutic potential of mesenchymal stem cell-derived exosomes. Cancer Sci. 111:3100. doi: 10.1111/ cas. 14563
Yamamoto, S., Azuma, E., Muramatsu, M., Hamashima, T., Ishii, Y., and Sasahara, M. (2016). Significance of extracellular vesicles: pathobiological roles in disease. Cell Struct. Funct. 41, 137-143. doi: 10.1247/csf.16014

Yang, J., Liu, X.-X., Fan, H., Tang, Q., Shou, Z.-X., Zuo, D.-M., et al. (2015). Extracellular vesicles derived from bone marrow mesenchymal stem cells protect against experimental colitis via attenuating colon inflammation, oxidative stress and apoptosis. PLoS One 10:e0140551. doi: 10.1371/journal. pone.0140551

Yeo, R. W. Y., Lai, R. C., Zhang, B., Tan, S. S., Yin, Y., Teh, B. J., et al. (2013). Mesenchymal stem cell: an efficient mass producer of exosomes for drug delivery. Adv. Drug Deliv. Rev. 65, 336-341. doi: 10.1016/j.addr.2012. 07.001

Yu, B., Kim, H. W., Gong, M., Wang, J., Millard, R. W., Wang, Y., et al. (2015). Exosomes secreted from GATA-4 overexpressing mesenchymal stem cells serve as a reservoir of anti-apoptotic microRNAs for cardioprotection. Int. J. Cardiol. 182, 349-360. doi: 10.1016/j.ijcard.2014.12.043

Yunusova, N. V., Tamkovich, S. N., Stakheeva, M. N., Afanas'ev, S. G., Frolova, A. Y., and Kondakova, I. V. (2016). "The characterization of exosome from blood plasma of patients with colorectal cancer," in Proceedings of the AIP Conference Proceedings (AIP Publishing LLC), (Melville, NY: AIP Publishing LLC), 20070. doi: 10.1063/1.4960289

Zhang, B., Wang, M., Gong, A., Zhang, X., Wu, X., Zhu, Y., et al. (2015a). HucMSCexosome mediated-Wnt4 signaling is required for cutaneous wound healing. Stem Cells 33, 2158-2168. doi: 10.1002/stem.1771

Zhang, B., Wu, X., Zhang, X., Sun, Y., Yan, Y., Shi, H., et al. (2015b). Human umbilical cord mesenchymal stem cell exosomes enhance angiogenesis through the Wnt4/ß-catenin pathway. Stem Cells Transl. Med. 4, 513-522. doi: 10.5966/ sctm.2014-0267

Zhang, Y., Yan, J., Liu, Y., Chen, Z., Li, X., Tang, L., et al. (2021). Human amniotic fluid stem cell-derived exosomes as a novel cell-free therapy for cutaneous regeneration. Front. Cell Dev. Biol. 9:685873. doi: 10.3389/fcell.2021. 685873

Zhao, J., Li, X., Hu, J., Chen, F., Qiao, S., Sun, X., et al. (2019). Mesenchymal stromal cell-derived exosomes attenuate myocardial ischaemia-reperfusion injury through miR-182-regulated macrophage polarization. Cardiovasc. Res. 115, 1205-1216. doi: 10.1093/cvr/cvz040

Zhou, H., Wu, S., Tang, X., Zhou, G., Yuan, J., Li, Q., et al. (2021). Chlamydia trachomatis infection in the genital tract is associated with inflammation and hypospermia in the infertile male of China. Asian J Androl. 23, 1-6. doi: 10. 4103/aja.aja_54_21

Zhu, Y., Feng, X., Abbott, J., Fang, X., Hao, Q., Monsel, A., et al. (2014). Human mesenchymal stem cell microvesicles for treatment of Escherichia coli endotoxin-induced acute lung injury in mice. Stem Cells 32, 116-125. doi: 10.1002/stem.1504

Conflict of Interest: The authors declare that the research was conducted in the absence of any commercial or financial relationships that could be construed as a potential conflict of interest.

Publisher's Note: All claims expressed in this article are solely those of the authors and do not necessarily represent those of their affiliated organizations, or those of the publisher, the editors and the reviewers. Any product that may be evaluated in this article, or claim that may be made by its manufacturer, is not guaranteed or endorsed by the publisher.

Copyright (C) 2022 Izadi, Dehghan Marvast, Rezvani, Zohrabi, Aliabadi, Mousavi and Aflatoonian. This is an open-access article distributed under the terms of the Creative Commons Attribution License (CC BY). The use, distribution or reproduction in other forums is permitted, provided the original author(s) and the copyright owner(s) are credited and that the original publication in this journal is cited, in accordance with accepted academic practice. No use, distribution or reproduction is permitted which does not comply with these terms. 